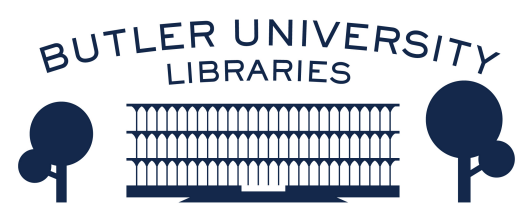

Journal of Hindu-Christian Studies

Volume 14

Article 16

January 2001

\title{
Book Review: "Religion and Public Culture: Encounters and Identities in Modern South India"
}

Ronald Neufeldt

Follow this and additional works at: https://digitalcommons.butler.edu/jhcs

Part of the Religion Commons

\section{Recommended Citation}

Neufeldt, Ronald (2001) "Book Review: "Religion and Public Culture: Encounters and Identities in Modern South India"," Journal of Hindu-Christian Studies: Vol. 14, Article 16.

Available at: https://doi.org/10.7825/2164-6279.1259

The Journal of Hindu-Christian Studies is a publication of the Society for Hindu-Christian Studies. The digital version is made available by Digital Commons @ Butler University. For questions about the Journal or the Society, please contact cbauman@butler.edu. For more information about Digital Commons @ Butler University, please contact digitalscholarship@butler.edu. 
discuss the Columbian legacy of "discovery" and its alternatives (1), and the framework of Gadamer and Derrida (2), they seem to repeat a great deal of what has already been said in post-Orientalist and cultural-hermeneutic circles. However, they are necessary groundwork for the highly original essays that follow. Dallmayr's style is similar to that of J. Z. Smith, in that each chapter suggests the outlines of an important scholarly project yet to be embarked on but crucial to the field. If other scholars take up Dallmayr's many incisive and creative suggestions, we shall have come a long way indeed.

Laurie Patton

Emory University

\section{Religion and Public Culture: Encounters and Identities in Modern South India. Keith E. Yandell and John J. Paul, Eds. Richmond,} Surrey: Curzon Press, 2000, 260pp.

THE CHAPTERS in this volume were originally presented at a conference to honor Professor Robert E. Frykenberg, well-known historian of south India. Happily the lead chapter in the volume is written by Frykenberg himself. As the title of the volume indicates the chapters are intended to deal centrally with the formation of religious identities and the importance of these identities as significant factors in public life. The volume is divided into two sections, the first dealing with orthodoxies and the second dealing with heterodoxies.

While the focus of the volume is modern India (generously interpreted to include developments in the 1700 's) not all of the chapters are about modern India. John B. Carman for example, writes about Pillan's (ca. 1100-1150) commentary on the Tiruvaymoli, by Nammalvar. To be sure, Carman does relate the commentary to the development of a distinctive Tamil Hindu community and to ongoing theological debate. This cannot be said about Keith $E$. Yandell's chapter on Persons "East and West", an attempt at cross-cultural analysis of self-awareness from the perspective of "Cartesian Jainism" on the one hand, and "Humean Buddhism" on the other. Nor can this be said of James D. Ryan's The Heterodoxies in Tamil Nadu. His study deals with the social and material factors in the development of Buddhist and Jaina influence in South India from the fourth to the sixth centuries C.E. He argues convincingly that, as it had in North India, that influence accompanied the development of urban culture in South India. More significantly the emphasis on individualism and self-effort in Jainism and Buddhism appealed to the warriors and merchants more than did the deities whose help the peasantry seemed to need. While one might question whether such an appeal to two psychologies ignores societal complexities, particularly within Hinduism, the author makes the provocative and useful suggestion that the social divisions implicit in his analysis may be a factor in the present day antiBrahmanism discussed in Kolenda's study of the Brahmins of Dharmarajapuram.

Frykenberg, in The Construction of Hinduism as a "Public" Religion: Looking Again at the Religious Roots of Company Raj in South India, argues persuasively that "Hinduism", as we now know it, is a recent phenomenon emerging as part of a large political process and that as a developing public system it became an integral element in the public administration of the British East India Company. Pamela G. Price, in Acting in Public versus Forming a Public: Conflict Processing and Political Mobilization in Nineteenth Century South India, focuses on the caste disputes in Masulipatnam, a town on the Andhra coast. 
She argues that the participants in these disputes took on new associational forms, in effect forming new types of public or political societies. Furthermore, the courts themselves, in defining caste membership supported the creation of new publics. Her distinction between acting in public and forming a public is useful in distinguishing what is new and what has pre-colonial precedents. Susan Billington Harper, in The Significance of Episcopal Extension for Church-Sate Relations in British India, discusses the consecration of Tamil missionary Vadanayan Samuel Azariah as Anglican Bishop for the newly created Dornakal Diocese. She argues convincingly that this consecration of the first indigenous Indian Anglican Bishop was achieved against great odds and through the manipulation of confusing legal and ecclesiastical procedures by two liberal bishops, Henry Whitehead and Reginald Coppleston. In The Drama of Conversions in the Courts of South India: Challenges to Aggressive Missionary Enterprise and Changing Judicial Attitudes in the Nineteenth Century, John J. Paul charts the changing attitudes of the courts to conversion to Christianity in the Madras territory. Important in these changes were the move to greater dependence on Indian law rather than English law, the religious beliefs and affiliations of judges and changing views on the age of a minor. In Routinized Charisma: The Case of Aurobindo and Auroville, Robert Minor uses Weber's theory on the routinization of charisma to argue that the Auroville's past and still current problems are a function of the fact that The Mother (Mirra Richard) did not see the need to pass her charisma on to anyone, and this in spite of the fact that Aurobindo had placed the leadership of the movement in her hands. In the process Minor provides us with a detailed and insightful account of the involvement of the courts and the Indian government in the fortunes of Auroville. Pauline Kolenda, in Memories of Brahman Agraharam in Travancore, traces the fortunes of the descendents of grantee Brahmin families living in Dharmarajapuram, a Brahmin street in Kanyakumari village. The author provides us with an insightful analysis of the "milestones" in the development of antiBrahmanism in Travancore. Particularly useful is the juxtaposition of the traditional place and roles of Brahmins in Dharmarajapuram with the current situation given largely through the voices of Brahmins themselves. In Cult Saints, Heroes, and Warrior Kings: South Asian Islam in the Making, Susan Bayly argues for the re-identification of South India as a place for the development of a regional but highly complex Islamic culture. Islam succeeded as a force in South India because it was interactive and accommodating. Bayly presents a compelling look at the way in which Islamic experiences, heroes and themes were mapped onto an existing sacred landscape.

Typographical errors notwithstanding, this is an excellent study of the formation of religious publics, their interaction with each other and with other publics. It deserves to be read by anyone interested in the religious history of India.

Ronald Neufeldt University of Calgary

\section{The South Asian Religious Diaspora in Britain, Canada, and the United States. Harold Coward, John R. Hinnels and Raymond Brady Williams, Eds. Albany: State University of New York Press, 2000, 301pp.}

ONE OF THE MOST significant and consequential developments in the religious history of the world during the latter half of the twentieth century is the transformation 